\title{
QUANTITATIVE ANALYSIS OF THE HUMAN RESOURCES DEVELOPMENT OPERATIONAL PROGRAMME SUPPORTING START UP OF BUSINESS ACTIVITY IN POLAND
}

\author{
Beata, Ślusarczyk ${ }^{1}$ and Beata, Borycka ${ }^{2}$ \\ ${ }^{1,2}$ Czestochowa University of Technology, Poland, jagoda@zim.pcz.czest.pl
}

\begin{abstract}
The aim of this article is to describe the rules for the use of the European Social Fund and the assistance provided under the Human Capital Operational Programme, in particular to draw attention to one of his priorities - Market open to everyone. One of the possible actions that the priority is to grant to start a business that contributes to the development of entrepreneurship in Poland. This report presents the results of the use of European funds allocated for this purpose and the number of people who benefited from the assistance offered in the different provinces.
\end{abstract}

KEY WORDS: The European Social Fund, Human Capital Operational Programme, Priority VI

\section{INTRODUCTION}

Along with the accession of Poland to the European Union appeared a possibility of using financial means as part of determined funds. European funds created with the thought about individual markets and areas responded to diagnosed problems. Its task became an aspiration to the development of regions and member states in many fields of life and among them of the entrepreneurship and the professional activation.

The main task of the European Social Fund is a market development achieved by promoting recruiting staff, maintaining previous places of employment and creating new, as well as supporting the high level of employment $[1,2,6]$.

The amount of means from the European Social Fund allocated for carrying defined actions out in years 2007-2013 amounts to about 75 bn euro, i.e. over 10 bn euro for each year. This budget increased by national and private measures intended to the co-financing of ESF projects amounts to an over $117 \mathrm{bn}$ euro [8]. The number of beneficiaries of the European Social Fund still grows, its increase in the period 2008-2012 shown in Figure 1.

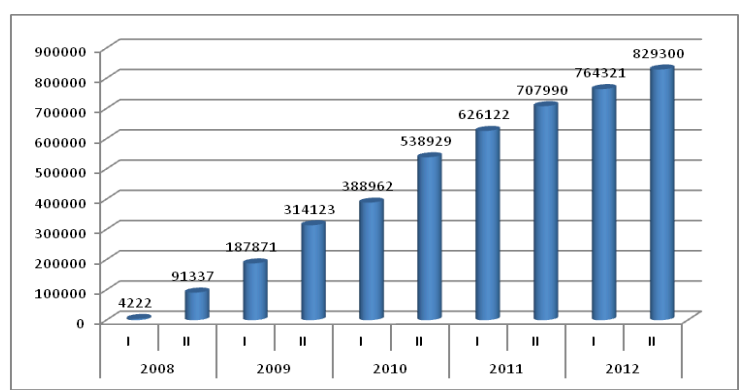

Figure 1. The number of people provided with supporting of the European Social Fund in Poland in years 2008-2012.

Source: Authors' study based on: www.efs.gov.pl/efekty/Strony/Zatrudnienie_i_rynek_pracy.aspx (access: 29.05.2013, 2:00 p.m.).

Before 31 December 2012, 829.300 people benefited from the European Social Fund. An average annual increase is over 165 hundred thousand. The most beneficiaries were recorded in the second half-year of 2010 - 149967 . From the beginning, that is from the first half-year of 2008, the number of people receiving the ESF financial assistance grew over 196 times, what means a great interest in offered supporting on the part of participants of individual projects.

Figure 2 shows the number of people using ESF in the division into individual provinces.

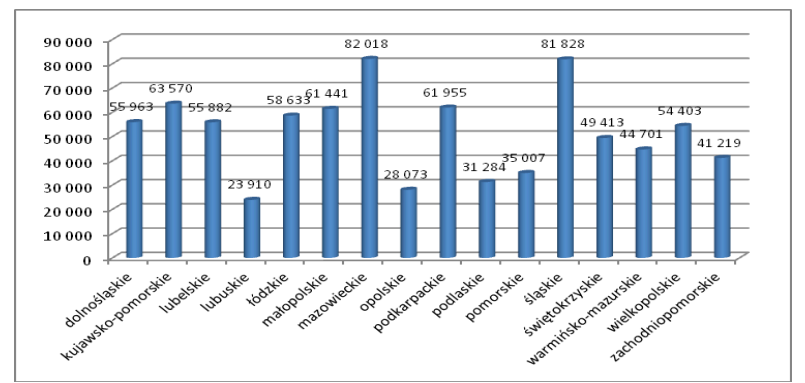

Figure 2. The number of people provided with supporting as part of the European Social Fund in individual provinces.

Source: Authors'own study based on: www.efs.gov.pl/efekty/ Strony/default.aspx (access: 29.05.2013, 2:00 p.m.).

In a group of provinces with the substantial amount of people which used subsidies offered by the European Social Fund were mazowieckie $(9.9 \%$ of the total number of beneficiaries) and śląskie $(9.9 \%)$. Fewest beneficiaries come from lubuskie $(2.9 \%)$ and opolskie $(3.4 \%)$ provinces.

\section{OPERATIONAL PROGRAMME HUMAN RESOURCES DEVELOPMENT CHARACTERIZATION}

Main objective of the Operational Programme Human Resources Development is "increase in the staffing level and the social cohesion. This purpose will be accomplished i.a. by professional activation, developing the adaptive potential of enterprises and their employees, picking up the level of education of the society, reducing areas of the social exclusion and supporting mechanisms of effective management in the Civil Service" [7]. 
Areas supported by the programme are: employment, education, social integration, development of employees and enterprises adaptivity, human resources development in rural areas, creation of effective and efficient civil service of all levels, as well as promotion of health amongst employees [5].

Enumerated aims, areas and priorities of the Operational Programme Human Resourced Development capital influenced above all on [3]: raising the quality in the sphere of human resources as a result of supplementing or acquiring new professional qualifications, of increasing employment, adapting potential new places of employment as well as levelling number of people which are in a situation of possible social exclusion; help in the development for these regions which are being counted to poorest; entering new solutions in the system functioning at present; raising the innovation of the Polish economy by efficient researches management. Table 1 presents a level of implementing the questioned programme in division into individual provinces.

Table 1. A level of implementing of the Operational Programme Human Resources Development in individual provinces.

\begin{tabular}{|c|c|c|c|}
\hline Voivodship & $\begin{array}{c}\text { Subsidy } \\
\text { number }\end{array}$ & $\begin{array}{c}\text { Subsidy } \\
\text { value } \\
\text { [thousand } \\
\text { PLN] }\end{array}$ & $\begin{array}{c}\text { EU } \\
\text { contribution } \\
\text { [thousand } \\
\text { PLN] }\end{array}$ \\
\hline dolnośląskie & 2291 & 2038802 & 1701368 \\
\hline $\begin{array}{c}\text { kujawsko- } \\
\text { pomorskie }\end{array}$ & 2048 & 1708554 & 1425332 \\
\hline lubelskie & 2715 & 2028055 & 1707171 \\
\hline lubuskie & 1181 & 732450 & 612616 \\
\hline łódzkie & 2875 & 2105911 & 1734255 \\
\hline małopolskie & 2588 & 2525700 & 2095308 \\
\hline mazowieckie & 4620 & 3786801 & 3164976 \\
\hline opolskie & 1250 & 804645 & 672733 \\
\hline podkarpackie & 2045 & 1941815 & 1609266 \\
\hline podlaskie & 1679 & 1080298 & 904640,2 \\
\hline pomorskie & 1825 & 1651364 & 1376688 \\
\hline śląskie & 3528 & 2777938 & 2320708 \\
\hline świętokrzyskie & 1944 & 1433777 & 1192789 \\
\hline $\begin{array}{c}\text { warmińsko- } \\
\text { mazurskie }\end{array}$ & 1901 & 1460429 & 1215973 \\
\hline wielkopolskie & 2847 & 2282851 & 1914146 \\
\hline zachodniopomorskie & 1563 & 1528041 & 1275277 \\
\hline
\end{tabular}

Source: Authors' study based on: www.mapadotacji.gov.pl (access: 05.04.2013 r., 10:40 a.m.).

The most subsidy - 4620 - found its way to beneficiaries from mazowieckie province constituting $12.5 \%$ of the total help granted and making this province the leader in this category, in the same way the value of the subsidy is also the greatest and exceeds 3.7 bn PLN. Next province - śląskie took advantage of backing up of over 2.7 bn PLN (9.6\%) intended to 3528 projects. The largest group of provinces $(47.2 \%$ of the total amount of the subsidy) are beneficiaries of above 2000 subsidies. They are: dolnośląskie, kujawsko-pomorskie, lubelskie, łódźkie, małopolskie, podkarpackie and wielkopolskie. Another seven voivodships are in the gropu of less than 2000 subsidies - podlaskie, pomorskie, świętokrzyskie, warmińsko-mazurskie and zachodniopomorskie, among them are two with the lowest figure of granted subsidies - lubuskie $(3,2 \%)$ and opolskie $(3,4 \%)$. The amount of the support for them did not exceed 805 million PLN. Altogether 36900 subsidies to the amount of 29887431 PLN were being granted in Poland, among which the contribution from European Union funds amounted to 24923 247 PLN (83.4\%).

Priority VI - "The labour market open for all" focuses on action being aimed at a professional activation of staying jobless and passive professionally people. The help, being granted as part of it, was directed at supporting young people (younger than 25 years), women (particularly single mothers, which are raising children), elderly people (older than 45 years), disabled people and people being unemployed for a long time, whose another introduction to the labour market is particularly timeconsuming and requires using many activation means. As part of the discussed priority are also offered actions directed at eliminating the phenomenon of the hidden unemployment, which in the large degree regards people living in rural areas, in particular from the centres of former State Agricultural Farms. The aid is being managed mainly for increasing the employability, what is supposed to be achieved by easier access to services from the area of the employment exchange and the career counselling, which have key importance in the initial phase of remaining jobless and are carried out above all through provincial and district Job Centres. One of the most important of the support are such forms of action, which leads to an increase or a change of professional qualifications by trainings, practices and courses, as well as gaining the professional experience in enterprises on individual workstations. An important aspect of the Priority VI, to which the greater attention is being paid, is an entrepreneurship development and employment itself, which displays in the support for measures having the task of the careers guidance, trainings and the financial and legal help for people planning to create their own business activity. Increasing offered service qualities by current Labour market institutions is equally important.

One of actions of the discussed priority, which enjoys considerable influence on the development of the business sphere in Poland, is action 6.2 - The support and the promotion of the entrepreneurship and self-employments. A managing authority for this action is a Department of Managing the European Social Fund, however a self-government body of the given province appoints the intermediary establishment. The primary aim of the action is "the promotion and supporting initiatives and solutions aiming to the job creation and development of creative attitudes, serving the entrepreneurship development and self-employment". The entrepreneurship development has an impact on the economic and social development of regions and the entire country, growth of the occupational activity, but first of all on the effective fight against the unemployment. According to conducted examinations for people wanting to establish their own enterprise on the market, the main barrier making it impossible, is a lack of adequate financial means. The differentiation of instruments and sources of finances, as well as elastic fitting forms of the support to needs of existing target groups decides largely on the effectiveness of the offered help. Significant seems fitting beneficiaries of ultimate given projects up with the adequate knowledge and competence concerning entrepreneurships both in the phase of assuming the new economic activity, as well as at the beginning of for her functioning. The help has two-way character [7]:

- non-refundable - directed above all at people being in particularly difficult conditions on the job market (i.a.: young, disabled persons, unemployed for a long time);

- refundable - granted as preferential loans to remaining beneficiaries (employees, students and graduates of colleges, academics which want to set up own business). 


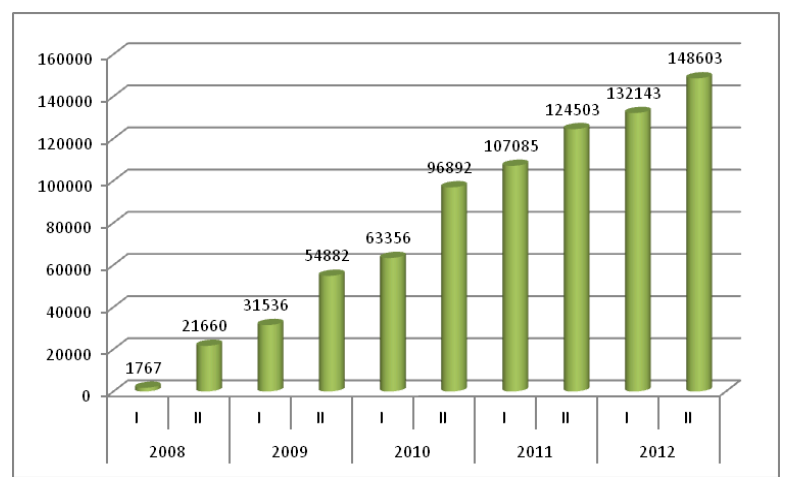

Figure 3. The number of people, which got funds to start a business activity as part of the Priority VI OP HRD in individual years.

Source: Authors' study based on: www.efs.gov.pl/efekty/Strony/ Zatrudnienie_i_rynek_pracy.aspx (access: 29.05.2013, 2:00 p.m.).

Within five years projects carried out by using means of the European Social Fund available as a part of the Operational Programme Human Resources Development included with its action 148603 people. From the first half of 2008 to the end of 2012 the number of people, using assistance intended to assuming their own business activity grew above 84 times. The greatest increase took place from the first to the second half of 2010 , but an average annual increment of people is about 29 thousand and on 2009/2010 it took out over 42 thousand.

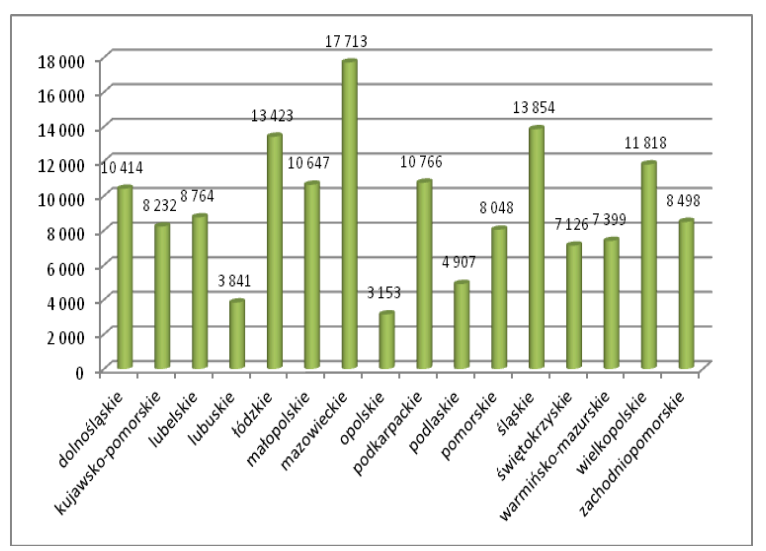

Figure 4. A number of people, which received financial means from OP HRD Priority VI or assuming their own business activity in individual provinces.

Source: Authors' study based on:

www.efs.gov.pl/efekty/Strony/Zatrudnienie_i_rynek_pracy.aspx (access: 29.05.2013, 2:00 p.m.).

Over 148 thousand persons throughout the country obtained subsidies to take their own business activity up. Among provinces which benefits the most from the EU help (with respect to the people which got funding) as part of the Priority VI OP HRD were: mazowieckie (11.9\%), śląskie (9.3\%), łódźkie $(9 \%)$ and wielkopolskie $(8 \%)$. The group of these provinces constitutes the $38.2 \%$ of all people which got funds for starting a business activity. Fewest people got subsidies in Opole province - only $2.1 \%$ in the scale of the entire country. In a group of provinces, in which the number of beneficiaries of the aid in question amounted below 7 400, were: lubuskie, podlaskie, świętokrzyskie and warmińsko-mazurskie, however the entire group constitutes the $17.7 \%$. Remaining regions being in a group from 7400 to 11800 of people, are a $44.1 \%$ of all beneficiaries.

\section{SUMMARY}

Subsidies from the European Union available as a part of the European Social Fund gave many people a chance of acquiring means intended for undertaking their own business activity. Such a possibility peculiarly exists in case of the Operational Programme Human Resources Development and its Priority VI - The labour market open for all. In financial perspective 20072013 beneficiaries of projects, which purpose was i.a. selfemployment and promotion of the entrepreneurship, were to the end of 2012148603 people, and residents of the Mazovian and Silesian provinces constituted their largest group. Projects carried out allow not only for creating and ensuring new places of employment, but also develop beneficiaries' enterprising abilities through the system of pre-trainings in conducting their own business activity, being a part of receiving the subsidy.

\section{REFERENCES:}

1. Grabara J., Kot S., Promotion of Employment Among Youth - Remarks for Next Initiatives. Annals of the University of Petrosani. Economics Vol. 8, No 1., 2008

2. Pachura P., Grabara J., Kot S. The Concept Of Intellectual Capital In Development Systems. Revista Economica 46, 3 2009.

3. Nalepka A., Ujwar-Gil A., Organizacje komercyjne $i$ niekomercyjne wobec wzmożonej konkurencji oraz wzrastajacych wymagań konsumentów, Wydawnictwo Wyższej Szkoły Biznesu w Nowym Sączu, Nowy Sącz 2009.

4. Rogoda B., Fundusze pomocowe Unii Europejskiej wspierajace przedsiębiorczość, Wydawnictwo Uniwersytetu Ekonomicznego w Krakowie, Kraków 2009.

5. Szymańska A., Fundusze UE 2007-2013 dla mikro, matych $i$ średnich firm, Wydawnictwo PLACET, Warszawa 2007.

6. Tkaczyński J. W., Willa R., Świstak M., Leksykon funduszy Unii Europejskiej, Wydawnictwo C.H. Beck, Warszawa 2009.

7. Szczegółowy opis priorytetów Programu Operacyjnego Kapitat Ludzki 2007 - 2013, Warszawa 2013.

8. ec.europa.eu. 